\title{
Checklist of the non-lichenised fungi of Fair Isle, Scotland
}

\author{
R. Watling ${ }^{1} \&$ N.J. Riddiford ${ }^{2}$ \\ 126 Blinkbonny Avenue, Edinburgh EH4 3HU \\ ${ }^{2}$ Schoolton, Fair Isle, Shetland ZE2 9JU \\ ${ }^{2}$ E-mail: taibnick@gmail.com
}

\begin{abstract}
A taxonomic list of the non-lichenised fungi recorded for Fair Isle is given. The total comprises 260 taxa: 251 verified species and 9 additional intraspecific variants. Several other entities remain provisional until fresh material is available. The list is annotated with summary details of abundance, distribution, habitat, phenology and, for notable species, their wider status within Britain. Four species are new citations for the British Isles. The list demonstrates the island's regional, national, international and conservation importance, particularly for grassland taxa and montane fungi associated with dwarf willow (Salix herbacea).
\end{abstract}

\section{INTRODUCTION}

Fair Isle is a small, isolated island just under $8 \mathrm{~km}^{2}$ in area, situated roughly half-way between Orkney and Shetland in the far north of Scotland. The earliest records of Fair Isle fungi are those of R.W.G. Dennis (RWGD). They were made between 1954 and 1986 and are mostly supported by vouchers in the fungarium at the Royal Botanic Gardens, Kew, London. In September 1985 R. Watling (RW), accompanied by Shetland naturalist Bobby Tulloch, made a two-day collecting visit as part of a wider survey of Shetland fungi. The findings were published in Watling \& Riddiford (1986, 1987) and Watling (1992). The last also incorporated records of the microfungi determined by RWGD (Dennis \& Gray, 1954; Dennis, 1972). As a follow-up to Watling (1992), a list of new finds for Shetland including Fair Isle was published in Watling et al. (2001). Subsequent records came from a six-year study, 2006-2011, by resident N.J. Riddiford (NJR) and a three-day visit in September 2011 by A. Murfitt (AM). Both focused on the "CHEGD" group of grassland taxa - Clavariaceae, Hygrocybe, Entoloma, Geoglossaceae and Dermoloma (Rotheroe et al., 1996) - leading to publications (Riddiford et al., 2019; Riddiford \& Watling, 2020a,b) and an unpublished report (Murfitt, 2011). Other records, derived from ad hoc collections by NJR with the help from interested Fair Islanders, have remained unpublished.

Most taxa collected after 1985, and certainly the critical ones, have been scrutinised by RW from material supplied by or through NJR, along with those collected by AM. Opportunistic collecting continues to be a regular source of records with increasing input from other interested Fair Islanders. Voucher specimens and/or photographs are either held with NJR at Schoolton, Fair Isle, or in the fungarium at the Royal Botanic Garden, Edinburgh (E). Most records are in OS $10,000 \mathrm{~m}$ square HZ27. Grid references for locations mentioned in the text are given in the Appendix. Several species previously placed in Omphalina have been found to be lichenised but because of their agaricoid morphology we include them here. For a full list of Fair Isle lichens, see Price (2017).

With records scattered, hard to find, and some in out-ofprint documents, the opportunity was taken to bring them together in this paper, both as a ready resource and as an update incorporating those not yet placed in the public domain.

\section{LIST OF FAIR ISLE FUNGI}

The list incorporates information for each species in the following order: scientific name; vernacular name(s), where known; Fair Isle status incorporating abundance, localities, substrate or habitat and fruiting body phenology - in summary form, or full dates for those rarely recorded. Additional details are given for species which achieve their northernmost known U.K. distribution and for species of particular conservation status. Nomenclature follows Index Fungorum (http://www.indexfungorum.org/names/names.asp) and Mykoweb (www.mykoweb.com). Synonyms or former names appear in parentheses after the name. Taxonomic treatment is included in square brackets where that differs from other interpretations of the taxon. Vernacular names are taken from http://www.britmycolsoc.org.uk/library/english-names/ new-english-names/ and http://www.davidmoore.org.uk/Assets/fungi4schools/R eprints/ENGLISH_NAMES.pdf.

References to Schoolton with no further detail relate to sheep-grazed semi-improved grassland reverting to unimproved. References to Ward Hill with no further detail relate to the $S$. herbacea montane heath of the Ward Hill summit north flank. The expression "Hill Grazings" refers to the upland, extensively grazed, moorland in the north of the island; "in-bye" is the southern half with its richer soils, agricultural land and crofting community. All determinations are by RW except where indicated. 


\section{A. TRUE FUNGI}

\section{Mushrooms, brackets and relatives} AGARICOMYCETES

\section{Agaricales}

Agaricaceae

Agaricus arvensis. Horse mushroom. Common, rough grazed grassland; fruiting variable from year to year but strong productivity at end of summer drought midAugust 2018, ten days later than Agaricus campestris emergence. A form with great fissures in the pileus has been named A. fissuratus but because of merging details it has been reduced to synonymy. It has been found in north and west Scotland's maritime grasslands. Known from Ward Hill (September 1985), Kenaby, South Haven and Ditfield.

Agaricus bernardii. Salty mushroom. Common, widespread, coastal grassland, grassy banks and roadside verges adjacent to sea such as above Mavers Geo, Utra Brae and (2020) in a line of 40 on South Light Brae; Autumn, extreme dates 5th September - 27th October.

Agaricus campestris. Field mushroom. Common, very occasionally super abundant, rich soil of moderately to strongly grazed grassland, in-bye, normally late July August; unprecedented numbers with first rains after prolonged drought from 4th August in 2018. A particularly squamulose form with slightly larger basidiospores has been separated as A. campestris var. squamulosus and is recorded from Byerwall and Barkland.

Agaricus cupreobrunneus. Copper mushroom, brown field mushroom. Frequent, widespread, in clusters, sheep-grazed grassland; fruits late August.

Agaricus macrosporus. Frequent, sometimes abundant, rough grazing; records include very large fruiting bodies near Taing, a tightly clustered row in grazed dung-rich grassland at Barkland, below The Haa, on burnside at Leogh and probably this species on a raised short-turf bank in fields east of Stonybreck; mainly mid August late September.

Chlorophyllum rhacodes (as Macrolepiota). Shaggy parasol. Coastal turf and improved grassland; two records - on deep soil, enriched by sheep droppings, Pund, September 1998 and clifftop, Linni Geo, October 2014. Only Shetland record.

Coprinus comatus. Shaggy ink cap, lawyer's wig. Frequent, largely unvegetated compacted substrates such as in-bye hardcore drives and in 1989 on the Hill, a ring of 100 thrusting through hard-packed stones and soil at the Lower Station communications mast; fruits September. This is the characteristic "inky cap", but most of the other species originally placed in Coprinus are unrelated and therefore placed in other genera; see Psathyrellaceae.

\section{Amanitaceae}

Amanita fulva. Tawny grisette. Rare. Ward Hill, 30th August 2010. Second Shetland record.

\section{Bolbitiaceae}

Agrocybe praecox (as A. gibberosa). Spring fieldcap. Rare or overlooked; recorded in small numbers, grassland, at Quoy. The name A. praecox covers a number of forms. The present collection was identified as A. gibberosa, which is often considered merely a variety, although the slender build and more arachnoid veil makes it distinctive.

Bolbitius vitellinus. Yellow fieldcap. Common, widespread; rotting vegetation and weathered dung. Considered by Index Fungorum as junior synonym of B. titubans but treated separately here.

Conocybe intrusa. Accidental introduction. Single fruiting body in compost imported to island, Barkland, September 2019. Only Shetland record. C intrusa is a U.K. non-native recently arrived from North America, originally found in botanic gardens and greenhouses but increasingly outdoors on compost or composted soil.

Conocybe vexans. Vexing conecap. Probable accidental introduction. Around 50 fruiting bodies in several clusters, compost imported to island, Barkland, August 2019. Only Shetland record.

Conocybe watlingii. Watling's downy conecap. In discarded household material mixed with pony dung, quarry at NE corner of Boini Mire, September 1985, and on horse dung, Barkland, March 2006 and March 2008. Watling (1992) assigned the name Conocybe neoantipus with the comment: "This collection is very close to Conocybe pubescens (Gillet) Kühner". However, the differences found between the holotype of the essentially North American agaric and the Fair Isle collection are sufficient to define two species.

\section{Clavariaceae}

Clavaria fragilis (as C. vermicularis). White spindles. Very common, widespread, coastal grassland, roadside verges and upper slopes of Ward Hill.

Clavaria fumosa. Smoky coral, smoky spindles. Multiple clumps, roadside bank just south-east of North Grind; annual 2011-2019, 28th August - 22nd September. Two clumps on bank of ditch, Pund, 22nd October 2019.

Clavulinopsis corniculata. Meadow coral. Abundant everywhere, clifftop turf, grassland and grassy heath to Ward Hill summit, even growing through hardcore drive at the Kirk. End August - late October.

Clavulinopsis fusiformis. Golden spindles. Very common throughout, close-cropped grassland from coast to Ward Hill. September - mid October.

Clavulinopsis helvola. Yellow club. Abundant throughout, unimproved grassland and particularly heath-grassland mosaics, some apparently attached to heather (Calluna vulgaris) roots, September - mid October.

Clavulinopsis laeticolor. Handsome club. Occasional, unimproved grassland and heath in north, 3rd - 5th September 2011 (AM). Only Shetland records.

Clavulinopsis luteoalba. Apricot club. Possibly montane, heathy grassland, Ward Hill, 27th October 2009.

\section{Cortinariaceae}

Cortinarius albonigrellus. Moderate population, Ward Hill, 14th October 2016, amongst the moss Mnium hornum but will be associated with nearby $S$. herbacea, the only ectomycorrhizal host present. Apparently new 
to Britain. Known from France, Norway, Finland, Russia and Turkey in montane and subalpine habitats with Salix spp. and other deciduous trees. Not listed by Legon \& Henrici (2005) (hereafter LH) for U.K.

Cortinarius anomalus. Variable webcap. Diminutive form with S. herbacea, Ward Hill, 6th September 1985. A related species lacking any blue flushes, with slight viscid pileus and spores faintly ellipsoid, has been called C. tabularis, and possibly found on loose rocky substrate with scattered $S$. herbacea and lichens, Ward Hill, 9th September 1989.

Cortinarius possibly caesionigrellus. One fruiting body, Ward Hill, 30th August 2010.

Cortinarius cinnamomeobadius. An abundant, wellestablished colony with creeping willow (Salix repens) in the wet south-east corner of Chatham's Land; recorded June and September. LH treat as junior synonym of $C$. croceus.

Cortinarius cinnamomeolutescens. Heathy grassland with $S$. repens near School, September 1985.

Cortinarius fulvosquamosus. Associated with S. repens, School, 7th September 1985. Only Shetland record.

Cortinarius obtusus s.l. Blunt webcap. Fairly common in rough grassland, Ward Hill, September - early October. Only Shetland record. Best treated as a complex of species; see C. scotoides and C. striatuloides below.

Cortinarius phaeopygmaeus. Two fruiting bodies with S. herbacea, Ward Hill, 27th October 2009. Second U.K. record. The first is from Ben Macdui, Cairngorm, 2002, also montane on peaty soil with $S$. herbacea.

Cortinarius cf. scotoides. Two, Ward Hill, 2nd October 2011. Similar in all ways to $C$. scotoides, but possesses more rusty brown coloration. LH give one record: Cairngorm, 1984, montane, on soil. A species in the C. obtusus group.

Cortinarius striatuloides. With S. repens, September 1985. LH treat as junior synonym of $C$. acutus but is sufficiently distinct to be retained as a full species based on its lack of cheilocystidia, spores less than $10 \mu \mathrm{m}$ long, clamp-connections, and small size of basidiomes.

Cortinarius triumphans. Birch webcap. Three fruiting bodies on $S$. repens, roadside, School, 1st September 2016. Only Shetland record.

Cortinarius trivialis. Girdled webcap. Small group with S. repens, wet peat and shallow pools, Chatham's Land, 4th September 1989.

Cortinarius uliginosus. Marsh webcap. Well established, S. repens-dominated pools, Chatham's Land; fruits early September.

Entolomataceae Pink gills. Incorporates all species previously placed in Leptonia and Nolanea, as well as Entoloma.

Entoloma ameides. Three fruiting bodies, flower-rich grassland, Chatham's Land, 19th August 2020.

Entoloma anatinum (as Leptonia). In rough grasslandheath mosaic, near School, 7th September 1985.

Entoloma atrocaeruleum. Navy pinkgill. Recorded from Schoolton, 14th September 2011 and two in short Festuca grassland, Vatstrass, 19th September 2020. Only Shetland records.
Entoloma atromadidum. Single fruiting body, rough grassland, near School, 28th September 2020. First Shetland record. Newly described, 2018, so wider status not yet ascertained.

Entoloma atromarginatum (as Leptonia). Wet heathy pasture, Ward Hill, September 1985. (See Entoloma nov. sp. below.)

Entoloma bloxamii. Big blue pinkgill, Bloxam's Entoloma. Near South Light HZ1982069850, 4th September 2011 (AM, as Entoloma bloxamii f. bloxamii) and rough grassland near School, 15th September 2020. First Shetland records of a nationally and internationally rare taxon. It is a U.K. BAP (Biodiversity Action Plan) species and on the provisional Red Data list. Recent studies have determined "E. bloxamii" as a cryptic complex of four taxa, two of which, E. bloxami s.st. and E. atromadidum, are known from Fair Isle.

Entoloma caesiocinctum (as Leptonia). Blue-girdled pinkgill. Roadside verge towards Bird Observatory, 6th September 1985.

Entoloma chalybaeum var. chalybaeum (as Leptonia). Indigo pinkgill. Heathy grassland near Bird Observatory HZ2193072147, September 2011 (AM).

Entoloma clandestinum (as Nolanea). Common throughout in sea pink (Armeria maritima) and sea plantain (Plantago maritima) dominated clifftop turf, unimproved grassland and amongst $S$. herbacea on Ward Hill; late August - mid October.

Entoloma conferendum. Star pinkgill. Commonest Entoloma, abundant throughout the island from A. maritima and $P$. maritima dominated clifftop turf and unimproved grassland to summit of Ward Hill amongst $S$. herbacea; September - October. Better known in many texts as Nolanea staurospora.

Entoloma corvinum (as Leptonia). Crow pinkgill. Schoolton, late August - September.

Entoloma elodes (often given incorrectly as E. "helodes"). Common in moorland pasture and particularly peaty marshland and mire, September. It is increasingly rare in northwest and central Europe due to habitat loss. It differs from E. fuscomarginatum particularly in the absence of a dark edge to the gill.

Entoloma exile (as Leptonia pyrospila). Roadside heading to Observatory, 6th September 1985.

Entoloma fernandae (as Nolanea). Grassy heath at HZ2094 73323, September 2011 (AM). Also known from coastal grassland, Sumburgh, so habitat differences (LH give unimproved grassland and coniferous woodland) possibly indicate different species within an aggregate.

Entoloma formosum (as Leptonia). Coastal turf, unimproved grassland and roadside verges; recorded as Leptonia fulva in September 1985 (RW) and as E. formosum s.1. with E. formosum s.str. at HZ22567239 in September 2011 (AM). A sienna-coloured capped form has been separated out as Leptonia fulva but now considered to belong to E. formosum. However, a diversity of field and microscopic characters suggests a complex of closely related taxa still to be resolved.

Entoloma griseocyaneum (as Leptonia). Felted pinkgill. Four, clifftop turf, Buness HZ2263372420, 4th September 2011 (AM). 
Entoloma hebes. Pimple pinkgill. Grassy heath, south flank of Ward Hill HZ20897338, September 2011 (AM). Only Shetland record.

Entoloma infula (as Nolanea). Schoolton, 29th September 2006.

Entoloma juncinum (as Nolanea). Schoolton, 25th September 2008.

Entoloma lividocyanulum (as Leptonia). Frequent, Schoolton, and two, clifftop, Field HZ2111771524, 5th September 2011 (AM). Only Shetland records.

Entoloma ?ochromicaceum. Schoolton, 14th September 2011. Two other U.K. records, Beinn Eighe, Wester Ross and Schiehallion, Perthshire, both in 2000.

Entoloma ortonii. Two fruiting bodies, 14th September 2011, Schoolton. Described from Shetland under the name Nolanea farinolens.

Entoloma papillatum (as Nolanea). Papillate pinkgill. Frequent, damp unimproved grassland, Hill Grazings, 4th September 2011 (AM). Recognised by the papillate, brown pileus and white immature gills.

Entoloma porphyrophaeum. Lilac pinkgill. Common, widespread, coastal grassland, heathy pastures and cliff top, 5th September 2011 (AM).

Entoloma prunuloides. Mealy pinkgill. Common, widespread, roadside verges and sheep pasture, September. E. prunuloides var. obscurum was recorded in clifftop heathy grassland, Furse, 5th September 2011 (AM). Only Shetland record.

Entoloma pseudoturci. Schoolton, 23rd September 2006. Only Shetland record. This species would be placed in Leptonia if the segregate genera were accepted.

Entoloma sericellum (as Leptonia and Alboleptonia). Cream pinkgill. Common, coastal heath, well-drained acid grassland, sheep pasture and moorland to Ward Hill summit. Early September.

Entoloma sericeum (as Nolanea). Silky pinkgill. Widespread throughout, often in large numbers, grazed grassland from clifftops to Ward Hill summit, mid July - early September. Three forms have been recognised: E. sericeum var. sericeum at HZ2089573376 and HZ2256572397, September 2011 (AM); E. sericeum var. cinereo-opacum, three at HZ2063070658, 3rd September 2011 (AM); only Shetland record; described for collections with an overall greyish coloration, even when drying; and E. sericeum var. nolaniforme, Schoolton, 26th August 2009 and Rippack HZ20647064, 3rd September 2011 (AM); only Shetland records; restricted to E. sericeum with the outward form of a Nolanea.

Entoloma serrulatum (as Leptonia). Blue edge pinkgill. Common, heathy pastures, as at Lower Station HZ21097321 and coastal grassland, as at Springfield. September.

Entoloma solstitiale (as Nolanea). Heathy grassland near Kirk, 3rd September 2011 (AM). Very close to E. conferendum but differs in the 4-sided, not distinctly stellate basidiospores and lack of mealy taste.

Entoloma undatum (as Eccilia). Schoolton, 26th September 2011. Only Shetland record.

Entoloma vernum (as Nolanea). Early spring pinkgill. Abundant but localised, late August - early September. Includes exceptional swarms of hundreds in A. maritima and $P$. maritime dominated coastal turf and coastal grassland at North Light, 8th September 1989.

Entoloma sp. Coastal grassland, Buness, 4th September 2011. Like E. papillatum but with distinctive dark edge to gills; likely to be a new species, not currently described according to AM/RW.

Hydnangiaceae

Laccaria laccata. Deceiver. Frequent, wet acid to baserich soils including Quoy and Springfield flush, June 2019. It differs from L. proxima in the globose spores. There is much variation within this taxon and some forms have been given specific identity, including a montane form. This variation is now considered insufficient.

Laccaria proxima (as Laccaria proximella, Mountain deceiver). Scurfy deceiver. Abundant as well as frequent at its one known site, north flank of Ward Hill. MidSeptember to mid October.

Hygrophoraceae Waxcaps

Arrhenia cf. parvivelutina. Ward Hill, on base-poor peaty soil, 6th September 1985. This differs from original description in lack of clamp-connections. Not in LH.

Cuphophyllus flavipes (as Hygrocybe). Yellow foot waxcap. One record, unimproved acidic grassland, September 2011 (AM). Recorded undoubtedly as H. lacma for Mainland Shetland.

Cuphophyllus pratensis (as Hygrocybe). Meadow waxcap. The island's commonest waxcap, very abundant throughout, unimproved, generally dry grassland from littoral to Ward Hill summit, end August - September and residually to early December. An overall ivory-coloured pale form - which has been called Hygrocybe pratensis var. pallida (synonym: Hygrocybe berkeleyi), pale waxcap or white meadow waxcap - is infrequent in sheep walk and unimproved grassland, as at Schoolton. September - early October.

Cuphophyllus russocoriacea (as Hygrocybe). Cedarwood waxcap. Schoolton, 6th October 2011.

Cuphophyllus virgineus (as Hygrocybe). Snowy waxcap. Common, unimproved and coastal grassland, including clifftops, September. The form with smaller stature, which is common on Fair Isle, has been traditionally separated as Hygrocybe nivea. Pinkish mottled fruiting bodies are frequently seen and have been called var. roseipes but it has been shown that the coloration is due to colonization by the fungus Fusarium sporotrichioides.

C. virginea var. fuscescens. Schoolton, 30th August 2011. Only Shetland record. Formerly considered a separate species.

Gloioxanthomyces vitellinus (as Hygrocybe). Possibly montane on acidic soils, Lower Station to Ward Hill, 5th September 2011 (AM).

Gliophorus irrigatus (as Hygrocybe). Slimy waxcap. Common, widespread in unimproved grassland, sheep walk and rough grassland-heath mosaic, first half of September.

Gliophorus laetus (as Hygrocybe). Heath waxcap. Abundant, often in large, dense groups on rather acidic, 
dry free-draining close-cropped grassland from low altitude to summit of Ward Hill, September-October.

Gliophorus psittacinus (as Hygrocybe). Parrot waxcap. Abundant throughout, unimproved grassland from littoral sites to Ward Hill summit, September - mid October. The concept adopted here is that of LH. Subsequent molecular studies have demonstrated the existence in British material of several cryptic species within a complex.

Hygrocybe aurantiosplendens. Orange waxcap. Two fruiting bodies, Schoolton, 19th September 2010. Close to $H$. quieta, which has similar spores but possesses an oily smell when rubbed and a more viscid pileus at first with less pronounced red.

Hygrocybe acutoconica var. acutoconica (as Hygrocybe persistens). Persistent waxcap. Relatively common, widespread, unimproved and maritime grassland, September.

Hygrocybe cantharellus. Goblet waxcap. Common, widespread, unimproved grassland, second half of September. Only Shetland records.

Hygrocybe ceracea. Butter waxcap. Very common, widespread, in-bye to Ward Hill summit, unimproved and maritime grassland, late August - mid October. Characterised by a viscid to greasy pileus but dry stipe. Hygrocybe chlorophana s.str. Golden waxcap. Highly abundant, unimproved and maritime grassland, late August - early October.

$H$. chlorophana var. flavescens $(=H$. euroflavescens). Often intermixed with $H$. chlorophana s.str., is also very common in roadside verges and grassland, noted at Buness, Chatham's Land, School and Schoolton, mid July - early October. These orange-yellow coloured forms have received full status as $H$. flavescens but are now considered no more than a variety.

Hygrocybe coccinea. Scarlet waxcap. Highly abundant, widespread, semi-improved and unimproved grassland, coastal turf and heath, early September - mid October. $H$. coccinea typically possesses a convex pileus but a distinctly umbonate variety has been bestowed the name $H$. coccinea var. umbonata - recorded at Schoolton, 11 th October 2010.

Hygrocybe conica. Blackening waxcap. Abundant, widespread. Semi-improved and unimproved grassland, early September. This has been demonstrated recently to comprise a mixture of cryptic species.

Hygrocybe conica var. pseudoconica ( $=H$. nigrescens). $S$. repens rich grassy heath near School, September 1985. This differs in its more robust stature and distinctly white base to the stipe. It is considered by some authorities to be a form of $H$. conica associated with $S$. repens beds.

Hygrocybe glutinipes. Glutinous waxcap. Frequent, unimproved bryophyte-rich grassland, end August October; records include a substantial colony in maritime grassland with scattered prostrate heather, lower slopes of Hoini, 16th October 2014. Its occurrence is known to be associated with the presence of pleurocarpous mosses.

Hygrocybe helobia. Garlic waxcap. Very common, widespread, in-bye to Ward Hill summit, unimproved grassland, particularly amongst moss on wet soils, sometimes in crowded patches, mid July - mid September.

Hygrocybe insipida. Spangle waxcap. Frequent, widespread, in-bye to Ward Hill north flank, acidic soil in unimproved grassland as well as neutral or relatively base-rich grassland and grassy areas, end August - late October. European Red List species.

Hygrocybe miniata. Vermilion waxcap. Very common, widespread, unimproved grassland and grassy heath, mid July to early October; records from roadside between Observatory to School, the Rippack, Schoolton and Chatham's Land. A form described from Britain (Hygrophorus strangulatus: orange-red waxcap) by Orton (1960) has strongly constricted basidiospores; this is not considered sufficiently distinct and Arnolds (1986) considers this to be the same as Fries' concept of Agaricus (= Hygrophorus) miniatus.

Hygrocybe mucronella. Bitter waxcap. Known from Schoolton, late August - mid September. Well characterised by the bitter taste and better known as H. reai.

Hygrocybe punicea. Crimson waxcap. Common, particularly along roadside verges, September - October. Hygrocybe quieta. Oily waxcap. Relatively common, widespread, neutral unimproved and coastal grassland; records include Buness, Schoolton and roadside between School and Bird Observatory, end August early October. European Red List species. An odourless form found at Schoolton, 30th August 2008 and 26th September 2016, has been equated with the concept of H. obrussea adopted by Orton (1960).

Hygrocybe reidii. Honey waxcap. Infrequent, scattered, unimproved grassland and sheep walk, September to mid October. Has been confused with $H$ marchii in Britain.

Hygrocybe, probably saliceti-herbaceae. With $S$. herbacea, montane heathy grassland and loose soil, Ward Hill, 11th October 2009.

Hygrocybe turunda. Schoolton, 18th September 2006. The concept adopted is that of Orton (1960) and Moeller (1945); see Watling (1992).

Lichenomphalia flava (as L. luteovitellina). Sunburst lichen. Unimproved montane grassland, S. herbacea zone, Ward Hill, predominantly May - August. Also recorded from clifftop grassland, north coast, 2nd June 2015 in Price (2017) as L. alpina, an alternative name reflecting its habitat preferences. It is not uncommon elsewhere in Shetland.

Lichenomphalia umbellifera (as L. ericetorum). Heath navel. Abundant all year, damp peat substrates, particularly wet eroded overhangs, sea level to Ward Hill summit; recorded as frequent and widespread in Price (2017). Omphalina fulvopallens, described from Scotland and applied to over-all pale coloured specimens with two-spored basidia from boggy areas, is now considered a synonym; it has been found on Ward Hill.

Lichenomphalia hudsoniana. Arctic mushroom scales. Montane, Ward Hill, anamorphic (asexual) Coriscium state, 6th September 1985; also recorded in Price (2017), 2nd June 2015. This taxon was described from North America; in Britain it is probably better known as 
Omphalina luteolilacina, under which name it is recorded from many sites elsewhere in Shetland.

Lichenomphalia velutina (as Omphalina grisella). On base-poor soil by trackside in short moss cover between Bird Observatory and School, September 1985. Only Shetland record.

Porpolomopsis calyptriformis (as Hygrocybe calyptriformis). Pink ballerina, pink meadow-cap, ballerina waxcap. Rare or overlooked, one record; fruiting body, low rough acid grassland, edge of airstrip, 22nd September 2019.

\section{Hymenogastraceae}

Galerina cerina (as G. cerina var. longicystis). Peaty soil, Ward Hill, September 1985. First U.K. record.

Galerina clavata. Ribbed bell. Two, on soil amongst mosses in grassy area, north flank of Ward Hill, 27th October 2009.

Galerina hypnorum. Moss bell. Dry heath, Rippack close to Kirk, 7th September 1985. Best treated as one of a complex of species.

Galerina paludosa. Bog bell. One record (but probably more widespread), small group, saturated Sphagnumrushy grassland, Lower Station, 12th August 2018.

Galerina pseudomniophila. Five basidiomes, all within $100 \mathrm{~cm}$, loose rocky substrate covered in $S$. herbacea and lichens but few flowering plants, Ward Hill, 9th September 1989.

Galerina pseudomycenopsis. Widespread known from coastal grassland, unimproved grassland (Schoolton) and Ward Hill, second half of August. First evidence was small clump, Meoness, 22nd August 2001. Recorded for Mainland Shetland as G. pseudopumila. Galerina pumila. Dwarf bell. Widespread, frequent, mid September to early November; can be plentiful e.g. numerous, Ward Hill, October 2009 and 2011, and ca. 15 in line amongst hypnum moss (Hypnum cupressiforme), Tarryfield, 5th November 2019. Commonly appears as the synonym Galerina mycenopsis.

Galerina subcerina. Peat soil, Barkland, September 1985.

Galerina terrestris (sensu Watling). Schoolton, 11th October 2010. This agrees in all ways with material from south Norway; it differs from G. vittiformis in the four-spored basidia and presence of ring-zone.

Galerina vittiformis. Hairy-leg bell. Common, Schoolton, late August - mid September. Easily recognised by the distinctly roughened basidiospores, prominent caul-, cheilo- and pleurocystidia but lack of similar cells on pileus. Commonly recorded in literature as G. rubiginosa.

Hebeloma mesophaeum. Veiled poison-pie. Plentiful amongst bryophytes, Ward Hill, 14th October 2016.

Psilocybe semilanceata. Liberty cap. Abundant throughout, semi-improved and dung-rich grassland, late August - September.

Psilocybe subcoprophila. Rare or overlooked; one record on dung, September 1985. Previously not always separated from $P$. coprophila, which differs in the much larger basidiospores.

Psilocybe subviscida (as P. bullacea). Occasional, Schoolton; also known (as a cluster of four) from
Chatham's Land; mid August - September. Recent research has shown that $P$. subviscida is rather variable and "P. bullacea", previously treated as independent, now has varietal status as $P$. subviscida var. velata. The species is easily confused with $P$. montana.

Inocybaceae

Inocybe fulvella. One record, with S. herbacea, Ward Hill, September 1985. Only Shetland record.

Lycoperdaceae

Bovista nigrescens. Brown puffball. Common, widespread, horse and sheep grazed coastal and acid grassland, clifftops to Ward Hill, late August - mid October.

Bovista plumbea. Grey puffball. Frequent, semi- and unimproved grassland, also, growing through compressed unmetalled track, Rippack, August - early September.

Lycoperdon excipuliforme. Pestle puffball. Four, roadside grass verge, Schoolton, 11th September 2014. Only Shetland record.

Lycoperdon nigrescens. Dusky puffball. Empetrum/Calluna heath, edge of airstrip and Ward Hill summit, September - early October.

Lycoperdon molle. Soft puffball. S. repens turf on peaty stony ground, near Schoolhouse, September 1985. Second Shetland record.

Vascellum pratense. Meadow puffball. Common, in-bye and north, coastal turf, unimproved acid grassland and roadside verges, late July - early September.

Lyophyllaceae

Calocybe gambosa. St. George's mushroom. Common at four known sites: grass verges at Quoy and at Wirvie, close-cropped maritime grassland above Hesti Geo and clifftop grassland at Kirki Geo, mid May - early June.

Rugosomyces carneus (as Calocybe). Pink domecap. Frequent, roadside verges, e.g. roadside heading to Observatory, near Taing, September.

Tephrocybe palustris. Sphagnum greyling. Clump of four, edge of very wet Sphagnum bog, Swey, 9th September 1989.

\section{Marasmiaceae}

Marasmius oreades. Fairy ring mushroom, fairy ring champignon. Two small clusters on clifftop, Linni Geo, 28th June 2015, one at roadside, Quoy, 16th June 2017 and two clumps at side of track, Midway, 25th May 2020 .

\section{Mycenaceae}

Mycena aetites. Drab bonnet. Widespread including close-cropped grassland at Schoolton, montane heath grass mosaic on north flank of Ward Hill summit and prostrate Calluna heath at Malcolm's Head, end August - end October.

Mycena epipterygia. Yellowleg bonnet. Widespread, acidic grassland and heath, September. Noted for the glutinous, yellow stem.

Mycena filopes. Iodine bonnet. Frequent on and under prostrate juniper (Juniperus communis ssp. nana), 
Swey, Breed Piece and Byerwall, October - mid November.

Mycena flavoalba. Ivory bonnet. Known from Schoolton, end September - early October.

Mycena leptocephala. Nitrous bonnet. Schoolton, 11th September 2006. LH report this species as "on soil or decayed leaf and woody litter (twigs, etc.) in deciduous and coniferous woodland....". Its appearance in grassland relates to $S$. repens - a widespread component of grassland in Fair Isle.

\section{Omphalotaceae}

Gymnopus dryophilus. Russet toughshank. Frequent from Setter north to Ward Hill summit, Empetrum/Calluna moorland and montane heath, September - mid October. Better known as Collybia dryophila. Fruiting body on Ward Hill parasitised by the fungus Syzygospora (Christiansenia) mycetophila q.v. Gymnopus alpinus. Alpine toughshank. One record: two fairy rings in close proximity, dry prostrate Calluna heath, south-facing aspect, Rippack, 20th May 2011. A recently described Arctic-alpine species now known to be widespread in montane areas of Scotland including Shetland. U.K. conservation status: notable.

\section{Pluteaceae}

Pluteus cervinus. Deer shield. One record: on buried wood, overgrown garden, Schoolton, 27th January 2009 .

\section{Psathyrellaceae}

Coprinopsis cordispora (as Coprinus). On fresh dung, Ward Hill, 2nd October 2011.

Coprinopsis laanii (as Coprinus). Loosely tufted group, oil-soaked wood chippings and old sawdust, car pit, Shirva, 24th January 2000. Only Shetland record.

Coprinopsis lagopides (as Coprinus and Coprinopsis jonesii). Post-fire inkcap. Sparsely vegetated ground at two localities: School grounds and Lower Stonybreck, March 2019; a second "crop" at Lower Stonybreck a month later. Only Shetland records.

Coprinopsis tuberosa (as Coprinus). Tuberous inkcap. One record, plentiful on rotted manure in garden, Barkland, 10th August 2020. Only Shetland record. Psathyrella panaeoloides. Schoolton, 23rd September 2006.

\section{Schizophyllaceae}

Schizophyllum commune. Splitgill. A recent colonist first recorded, group of 12, facing east on sea-borne soft wood trunk lifted from sea a few months earlier, Quoy, 10th October 2015, followed by three autumn records in 2020: $c a$. six on exposed weathered silage, Midway, 17th September 2020; two clusters, growing from slits in silage bags, Quoy, 4th October 2020; one on year-old silage, Setter ca. 12th October. Northernmost U.K. records. S. commune has come a long way from being rare in mid-20th century to expanding its range throughout the U.K. with a special liking for exposed silage.
Strophariaceae

Deconica Horizontalis. Wood oysterling. Rare, one record: four fruiting bodies on underside of wooden ladder, Finniquoy gully, 18th July 2015. Only Shetland record. Better known as Melanotus, a genus based on the pleurotoid aspect of the fruiting bodies.

Deconica inquilina. Flecked brownie. Common at Schoolton; first evidence, 14th September 2008, end August - end September. Only Shetland records.

Deconica montana. Mountain brownie. Common, known from Lower Stonybreck (roadside) and Schoolton, mainly September but outlier 20th February 2018. The Schoolton samples include material with slightly larger basidiospores, a form sometimes separated as "Psilocybe physaloides" but not now considered worthy of separation.

Hypholoma elongatum. Sphagnum brownie. Known from acidic bog, Sukka Mire, 6th September 1989.

Hypholoma ericaeoides. Common, wettest parts of Sphagnum bog across Hill, e.g. ca. 20, scattered in the wettest part of a very wet Sphagnum bog, Swey, 9th September 1989.

Hypholoma ericaeum. Frequent in moss on wet peaty soil, e.g. Byerwall, September.

Hypholoma fasciculare. Sulphur tuft. Rare, one record: two clusters, base of fence post, 6th April 2019.

Hypholoma subericaeum. Occasional, widespread, on disturbed soil; classically in swarms of 100 or more amongst rotting vegetation thrown up during ditch excavations, September - October.

Protostropharia semiglobata (as Stropharia). Dung roundhead. Abundant across the island on weathered dung, grassland, heath and clifftops, June - early November. A collection on pony dung, NE Boini Mire quarry, 7th September 1985, was identified as var. stercoraria because of its flattened pileus and large size but it does not warrant separation.

Agaricales: Family uncertain. The listing of the genera of Agaricales below is not intended to mean that they possess a close relationship to each other, but only that they cannot, as yet, be placed in the main classification of agarics.

Gamundia striatula. Lined meadowcap. Grazed maritime grassland, Buness, September 1985.

Lepista multiformis (as L. multiforme). Fruiting bodies frequent and abundant at four known sites: amongst hypnum moss, crowded, ca. 100 within 30 m radius, on mossy part of airstrip in 1989; neutral grassland at Eas Brecks in 2013; maritime grassland at Hjukni Geo in 2013 and 2019; and base of Hoini in 2020. Arctic-alpine species, rare in U.K. This taxon differs from L. ovisporum, of which there is a possible collection from Fair Isle, in its more robust habit and larger basidiospore size.

Lepista nuda. Wood blewit. Common, strictly coastal, rocky south-facing slope, Utra Brae, under cliff edge above Hesti Geo, Swarts Geo, above North Haven beach, Bullock Holes, above North Naaversgill, edge of Grand Canyon (Breed Piece); rarely from early October but normally end October - early December. 
Lepista panaeola. Rare, single record: acid grassland/heather mosaic, above Wester Lother, 9th November 2019.

Melanoleuca schumacheri. Clouded cavalier. Close cropped acidic grassland, Airstrip roadside verge, 14th October 1989.

Tricholomopsis rutilans. Plums and custard. Occasional, rotting fence post, disturbed soil and welldrained grassland, Vaadal Plantation, Bullock Holes, Wirvie, Barkland, mid August - late September.

Panaeolina foenisecii. Brown mottlegill, brown haycap. Abundant throughout island, dung-rich grazed grassland, mainly mid July into October.

Panaeolus acuminatus. Dewdrop mottlegill. Schoolton, 9th October 2011. Determination as outlined by Hora (1957); it is difficult to separate from P. rickenii q.v., except the basidiome is generally not as slender and the pileus broader and often with a constriction toward the apex.

Panaeolus fimicola. Turf mottlegill. Common, Schoolton, late August - early October. A very dark form that has been separated as $P$. ater found at Schoolton, two basidiomes on 23rd September 2006 and at Valsbrough, two on 26th April 2019.

Panaeolus rickenii. Very common, dung-enriched grassland, Observatory to School and Schoolton, mid September - early October. Although LH treat this as a junior synonym of $P$. acuminatus, in our view it is sufficiently distinct to remain as a separate species.

Panaeolus semiovatus. Dung mottlegill. Very common, grassland on dung, including pony dung middens at Boini Mire and Barkland; also recorded Kenaby, Quoy and near School; all months, particularly in spring.

Panaeolus papilionaceus. Petticoat mottlegill. Dungrich semi-improved grassland at Schoolton, September. This species is perhaps better known as P. sphinctrinus.

\section{Auriculariales}

Auriculariaceae

Auricularia auricula-judae. Jelly ear, Jew's ear fungus. Short-lived introduction. Colony on slab of heart-wood or teak set in a concrete base, new slipway, North Haven, 4th June 2001. Only Shetland record.

\section{Boletales}

Hygrophoropsidaceae

Hygrophoropsis aurantiaca. False chanterelle. Known from a solitary example in damp, poor grazing pasture mainly of moss and $S$. repens, Rippack, 4th September 1989.

\section{Cantharellales}

Hydnaceae

Clavulina cinerea. Grey coral. Localised, montane, several small "swarms" in grassland with $S$. herbacea, Ward Hill, 6th September 1985.

\section{Hymenochaetales}

Rickenellaceae

Rickenella fibula. Orange mosscap. Common at Schoolton, also known from Ward Hill, end August mid September. Better known and cited in many texts as Mycena or Omphalina fibula.
Rickenella swartzii. Collared mosscap. Common, Schoolton, mid - end September.

\section{Polyporales}

Fomes fomentarius. Hoof fungus, tinder bracket. Shortlived adventive. On driftwood, probably birch (Betula sp.), undated but late 20th century. Specimen destroyed when wood burned on croft house fire. Only Shetland record.

Gloeophyllum sepiarium. Conifer mazegill, rusty-gilled polypore. Infrequent; an efficient "rotter", destroying pine framework to windows and walls, older buildings, in-bye; dated records from Lower Stonybreck, 6th March 1998 and colony on window frame of old hut, Quoy, 13th August 2014. Only Shetland records.

\section{Russulales}

Bondarzewiaceae

Heterobasidion annosum. Root rot, root fomes. Base of ca. 50 year old fence post, probably of larch (Larix sp.), Quoy, 18th June 1996. Only Shetland record.

Russulaceae

Lactarius lacunarum. Very common with $S$. herbacea, Ward Hill and S. repens at Chatham's Land and roadside near Kirk, first half of September.

Lactarius lanceolatus. Abundant. Montane grassland and stony S. herbacea-lichen heath, Ward Hill, August - November, peaking October. Annual, first recorded 19th August 1998. Second U.K. and Shetland record (Arctic-alpine).

Russula densifolia. Crowded brittlegill. Several on stony $S$. herbacea heath, Ward Hill, 11th and 14th October 2016. Only Shetland records.

Russula felleaecolor. Plentiful, Ward Hill, 2nd October 2011. First confirmed British record. Described originally from the Italian Alps.

Russula fragilis. Fragile brittlegill. With S. repens, Rippack and Rippack clifftop, 7th September 1985.

Russula medullata. Occasional amongst S. herbacea, Ward Hill; first evidence September 1985; small numbers at same site, 17th October 2008, 11th and 12th October 2009. Only British records (Arctic-alpine). Agrees in all ways with collections of this agaric, recently described from arctic alpine communities (Kühner, 1975).

Russula nana. Alpine brittlegill. Common, stony S. herbacea-lichen heath, Ward Hill and alongside semipermanent rain pools, moss, lichen and $S$. repens rich wet grassland on the Rippack; probably associated with roots of Salix; October. Formerly treated, including in Watling (1992), incorrectly as $R$ alpina.

Russula norvegica. Occasional, Ward Hill, September October; first evidence September 1985. U.K. Red Data List. One other Shetland record. LH treat this as junior synonym of $R$. laccata, but some authorities considered $R$. norvegica distinct - an opinion followed here.

Russula pallescens. Three, one fresh, Ward Hill, 13th September 2017. Second U.K. record.

Russula pascua. Pasture brittlegill. With S. repens, Rippack and S. herbacea, Ward Hill, September - mid October. Full distribution unclear but recorded from 
many montane areas of Scotland and common in Shetland.

Russula persicina. Weathered basidiomes recorded, Ward Hill, September 1985.

\section{Thelephorales}

Thelephoraceae

Thelephora terrestris. Earth fan. Short-term introduction, probably with compost or trees; colony on soil and base of trunk, imported oak (Quercus sp.) sapling, in pot outside house, Lower Stonybreck, 9th July 2001. Did not persist.

\section{Jelly fungi}

\section{DACRYMYCETES}

\section{Dacrymycetales}

Dacrymycetaceae

Calocera viscosa. Yellow stagshorn. On timber from derelict war-time building, Ward Hill, September 1985. Very unusual on worked wood. Second Shetland record. Dacrymyces stillatus. Common jellyspot. Relatively frequent on decaying worked wood, planks and old untreated fence posts. All year.

\section{EXOBASIDIOMYCETES}

\section{Tilletiales}

Tilletiaceae

Tilletia sphaerococca. On common bent (Agrostis capillaris), Ward Hill, 30th July 2004. Second Shetland record.

\section{TREMELLOMYCETES \\ Tremellales}

\section{Carcinomycetaceae}

Syzygospora mycetophila. Collybia jelly. Parasitic on Gymnopus dryophilus (=Collybia dryophila), Ward Hill, 14th October 2016. Only Shetland record.

\section{Rust fungi and smuts \\ PUCCINIOMYCETES \\ Pucciniales}

\section{Coleosporiaceae}

Coleosporium tussilaginis. Frequent. On various eyebrights including Euphrasia arctica and E. foulaensis, August. Sometimes treated as separate entity, C. rhinanthacearum.

\section{Gymnosporangiaceae}

Gymnosporangium clavariiforme. Tongues of fire, juniper rust. Substantial colony on single prostrate juniper, Breed Piece, 9th April 2010. Only Shetland record.

\section{Melampsoraceae}

Melampsora epitea. Willow leaf rust. Common, particularly around the School, on S. repens leaves, often in heavy clusters of orange spots, July-August.

Melampsora caprearum. Goat willow leaf rust. Rare, on leaves of introduced Salix cf. cinerea, Vaila's Trees, 11th September 2019. Only Shetland record.
Pucciniaceae

Puccinia arenariae. On leaves of red campion (Silene dioica), garden, Schoolton, 25th June 2009. Probably under-recorded.

Puccinia obscura. Occasional. On field wood-rush (Luzula campestris), summer. Alternate host is common daisy (Bellis perennis), which is common on island.

Puccinia punctiformis. Thistle rust. Very common, on creeping thistle (Cirsium arvense), mid June - August, peaking July.

Puccinia urticata. Nettle clustercup rust. Common, occasionally as heavy gall infestations, on nettles (Urtica dioica) (aecidial stage) at Pund and Bullock Holes, mid - late June. This is a member of the $P$. caricina complex with alternate hosts sedges (Carex spp.).

Pucciniastraceae

Melampsorella caryophyllacearum. Reported by RWGD with no further detail.

\section{USTILAGINOMYCETES}

Ustilaginales

Microbotryaceae

Microbotryum violaceum (as Ustilago violacea). Reported by RWGD, undated, on anthers of sea campion (Silene maritima).

\section{Ustilaginaceae}

Ustilago striiformis. Stripe smut of grasses. On Yorkshire fog (Holcus lanatus), roadside, in-bye, 19th September 2016. Probably common but overlooked.

\section{Cup fungi and relatives PEZIZOMYCETES \\ Geoglossales}

Geoglossaceae

Geoglossum barlae. Rare, lower slopes of Ward Hill, September 2011 (AM). Only Shetland record. Vulnerable, according to the Fungi Red Data list for Britain and Ireland.

Geoglossum cookeianum. Earthtongue. Frequent in acidic grassland, slopes of Ward Hill, 5th September 2011 (AM).

Geoglossum fallax. Deceptive earthtongue. Occasional, sometimes abundant as at Kenaby where hundreds scattered through dry well-drained close-cropped grassland in late October 1989; also known from Ward Hill summit north flank; October.

Geoglossum nigritum. Scarce. Mossy heath, September 1985. Probably one of Britain's commonest earthtongues.

Geoglossum starbaeckii. Star earthtongue. Rare, single spike on saturated soil, mat-grass (Nardus stricta) dominated acid grassland, clifftop, Rippack, 19th September 1998. Only Shetland record.

Geoglossum umbratile. Plain earthtongue. Scattered, mossy grassland in north, 3rd and 5th September 2011 (AM). Only Shetland records.

Microglossum olivaceum. Olive earthtongue. Several groups of two to three spikes per group, buck's-horn plantain (Plantago coronopus)-red fescue (Festuca rubra) coastal turf, free draining clifftop slope, Utra 
Brae overlooking Shalstane, 18th September 1998; fruiting bodies appeared to be attached to the plantain. First for Shetland, fifth Scottish record. On the Red Data list and a U.K. BAP species.

\section{Helotiales}

Drepanopezizaceae

Leptotrochila cerastiorum. Reported by RWGD, undated, on fading leaves of common mouse-ear chickweed (Cerastium fontanum). Only Shetland record.

\section{Erysiphaceae}

Erysiphe knautiae. Scabious mildew. Probably common, widespread, on devil's-bit scabious (Succisa pratensis) leaves, rough grassland, late summer autumn.

Gelatinodiscaceae

Phaengellina empetri. On dead attached leaves of crowberry (Empetrum sp.), September 1985. Probably common but overlooked.

\section{Helotiaceae}

Hymenoscyphus calyculus. Rare or overlooked, several on stick in garden, Barkland, 10th July 2020. Only Shetland record.

\section{Sclerotiniaceae}

Myriosclerotina curreyana. Probably widespread but overlooked, known on jointed rush (Juncus articulatus), waterlogged mires and flushes, Sukka Mire and Springfield, June.

\section{Pezizales}

Ascobolaceae

Ascobolus denudatus. Three on soil among potato shards, garden, Lower Stonybreck, 24th September 2001. Only Shetland record.

Ascobolus furfuraceus. Reported by RWGD, undated, with no further detail.

Saccobolus obscurus. Reported by RWGD, undated, on sheep droppings.

Saccobolus versicolor. Reported by RWGD, undated, on rabbit pellets.

\section{Pezizaceae}

Iodophanus carneus. Widespread, on dung.

Peziza cerea. Cellar cup. Infrequent, wet plasterboard in out-buildings and damp housing; Nissen hut, 1981, North Haven; inside lounge wall, Schoolton, 7th June 1995 and other side of same wall, Schoolton kitchen, 12th July 1995.

Peziza domiciliana. Carpet cup, domicile cup fungus. Several fruiting bodies clustered on soil, grassland halfburied with cast-out garage and household material, Shirva, 6th April 2019. Only Shetland record. Characterised by very faintly verruculose ascospores. Peziza vesiculosa. Blistered cup, common dung cup. On horse and pony dung, Barkland, 17th June 2006. Only Shetland record.
Pyronemataceae

Aleuria aurantia. Orange peel fungus. Two records: $c a$. 50, dry disturbed ground, Vaadal gully, 9th October 1989, and small cluster on turned-over bare soil, Brekkawalls, 28th September 2020.

Cheilymenia raripila. Reported by RWGD, undated, on rabbit pellets.

Neottiella vivida. Occasional. In small colonies amongst rocks, soil and sparse vegetation, Lower Station and Ward Hill.

Scutellinia olivascens. Little skullcap. Rare adventive. Several strong groups, wet clay soil, footpath, back of Houll, 28th October 2015. Only Shetland record. Vector for spores could be birdwatchers' boots.

Tricharina gilva. Small cluster, ash-rich soil, The Haa, 11th September 2016.

\section{Uncertain position}

Coprotus aurora. Reported by RWGD, undated, on rabbit pellets. Only Shetland record.

Coprotus sexdecimsporus. Reported by RWGD, undated, on sheep dung.

\section{Rhytismatales}

Rhytismataceae

Lophodermium juniperinum. Juniper split. Reported by RWGD, undated, on juniper. Only Shetland record.

Rhytisma salicinum. Willow tarspot. Abundant on $S$. herbacea leaves, Ward Hill, late June - July. Not found yet on S. repens.

\section{SORDARIOMYCETES}

\section{Hypocreales}

Calcarisporiaceae

Calcarisporium arbuscula. On Agaricus cupreobrunneus, below Burkle, 23rd August 2018. Only Shetland record. Endophyte of discomycetes, occasionally on agarics. An anamorphic taxon lacking evidence of a sexual stage.

\section{Clavicipitaceae}

Claviceps purpurea. Ergot. Common to abundant on sweet vernal grass (Anthoxanthum odoratum) capitula, particularly roadsides (e.g. Gilsetter roadside), occasional on mat-grass and infrequent on perennial rye-grass (Lolium perenne); records only as sclerotia, these evident first in mid summer, well-developed by late August - September.

Cordyceps gracilis. Rare or overlooked. Ward Hill, 3rd July 2010.

Cordyceps militaris. On buried caterpillar, September 1985.

\section{Nectriaceae}

Fusarium sporotrichioides. Fusarium head blight. On snowy waxcap Cuphophyllus virgineus Schoolton, 19th September 2016. An anamorphic taxon lacking known sexual stage.

\section{Magnaporthales}

Magnaporthaceae

Gaeumannomyces graminis. Take-all. Dark brown structures on cultivated oat (Avena sativa) heads, Upper 
Leogh, 13th December 2017. This would be G. graminis var. avenae (Turner), according to Dennis (1960).

\section{Phyllachorales}

Phyllachoraceae

Phyllachora graminis. Common grass tar spot, black leaf spot of grasses. Frequent on couch grass (Agropyron repens) leaves, roadside, Leogh, 19th June 2020.

Phyllachora sylvatica. Fescue black leaf spot, fescue tar spot. Frequent on leaves of red fescue in semi-improved and ungrazed rough grassland, from late June.

\section{Sordariales}

Lasiosphaeriaceae

Schizothecium conicum. On sheep droppings, September 1985.

Schizothecium vesticola. On sheep droppings, September 1985.

\section{Sordariaceae}

Sordaria minima. On rabbit droppings, September 1985.

\section{Xylariales}

Amphisphaeriaceae

Physalospora empetri. Reported by RWGD, undated, on dead attached twigs of crowberry. Only Shetland record. But highly likely to occur elsewhere in the archipelago.

\section{Diatrypaceae}

Diatrypella favacea. Birch blackhead. Casual introduction. Abundant fruiting bodies on silver birch (Betula pendula) trunk, Shirva, 15th October 2013. Imported from Norway on wood destined for carpentry and destroyed.

\section{DOTHIDEOMYCETES}

\section{Hysteriales}

Hysteriaceae

Gloniopsis praelonga. On Salix bark (an atypical host), Plantation, 25th August 2016 (Brian Coppins). Often misidentified as the lichen Graphina ruiziana but the latter has iodine-positive purple brown spores whereas $G$. praelonga has iodine-negative spores.

\section{Pleosporales}

Didymellaceae

Epicoccum purpurascens. On perennial rye-grass, Schoolton, 11th September 2006. Probably common but overlooked. An anamorphic taxon with no known sexual stage.

Pithomyces chartarum. Lamb's ear. Isolated cases on sheep, Hill Grazings. There is possibly a causal relationship with parched grasses in dry summers, as in 2018 (according to Iain Stout, crofter). Only Shetland record. An anamorphic taxon with no known sexual stage.

\section{Mycosphaerellaceae}

Ramularia pratensis. Reported by RWGD, undated, on common sorrel (Rumex acetosa). Only Shetland record.
Causes round or elliptic pale brown-purple to redbordered lesions on Rumex species. An anamorphic taxon.

Septoria scabiosicola. Rust spots on leaf of devil's bit scabious, below Stackhoull Stores, 22nd August 2015. An anamorphic taxon.

Phaeotrichaceae

Trichodelitschia bisporula. Reported by RWGD, undated, on rabbit pellets. Only Shetland record.

Pleosporaceae

Dilophospora alopecuri. Twist, plumed spore disease of cereals. On Yorkshire fog leaves, Schoolton, 19th September 2016. An anamorphic taxon.

\section{Uncertain position: Hyphales ("Hyphomycetes")}

Endoconospora cerastii. Reported by RWGD, undated, on mouse-ear chickweed (Cerastium fontanum); only Shetland record. An anamorphic taxon.

\section{True moulds MUCOROMYCETES}

Mucorales

Pilobolaceae

Pilobolus crystallinus. Dung cannon. Reported by RWGD, with no further detail.

\section{Entomophthorales}

Entomophthoraceae

Conidiobolus coronatus. Relatively common in gardens; characterised by classic moribund Diptera at apex of plants; summer. Only Shetland records.

\section{B. "FAKE FUNGI"}

A group of organisms previously considered to be fungi and studied as such by mycologists.

\section{Chromista \\ OOMYCOTA \\ Peronosporales}

Peronosporaceae

Peronospora rumicis. Sorrel downy mildew. Reported by RWGD with no further detail. A downy mildew on common sorrel and sheep's sorrel (Rumex acetosella).

Phytophthora infestans. Potato blight. Common, on potato (Solanum tuberosum). A persistent pest of potato rigs, particularly prevalent in damp hollows such as Houll Cuppas and during damp summers.

Plasmopara densa. Downy mildew. On eyebright (Euphrasia sp.), Buness, 13th August 2018.

\section{Plasmodiophorales}

Plasmodiophoraceae

Plasmodiophora brassicae. Club root, finger-and-toe. Occasional in gardens on brassicas. Also reported by RWGD with no further detail.

\section{Protista (slime moulds and others) Stemonitidea \\ Didymiidae}


Mucilago crustacea. Dog sick slime mould. Common and widespread, on ungrazed rough grassland, particularly roadsides, in-bye, end of summer; extreme dates 11th August and 10th October; short-lived, degrading within a few days. Only Shetland records.

\section{Physarida}

Physaridae

Fuligo septica. Scrambled egg slime, flowers of tan. Small group, north slope of Utra Brae, 7th May 2016. First for Northern Isles.

\section{DISCUSSION}

From the 52 taxa appearing in Watling \& Riddiford (1986), the tally has grown to 260, nine of which are additional intraspecific variants. Several further entities remain provisional until fresh mature material becomes available. Watling (1992) listed 989 taxa for Shetland, with a further 62 unconfirmed or not identified to a known species. The Fair Isle totals are only a quarter of that number and, notably, a number of common Shetland fungi are absent. The lower proportion and absentees can be attributed to several factors: much smaller land area; more restricted range of substrates and habitats, not least the absence of trees; and, perhaps, some imbalance in the intensity of collecting between the two areas. Most importantly, the geographical isolation of an island $34 \mathrm{~km}$ from the nearest land mass (the southern tip of Shetland Mainland) will have its effect. This has been illustrated for two other wellworked taxonomic groups - vascular plants and spiders. Fair Isle shares only $40 \%$ of the Shetland flora (Quinteros Peñafiel et al., 2017; Scott \& Palmer, 1987) and there are some notable absentees. The spider diversity is more complete but still $30 \%$ short of the full Shetland fauna (Milner, 2006; Riddiford, unpublished data).

Lower diversity does not equate to diminished biodiversity. The current list includes four taxa that are first notifications for the British Isles and three for the second time. A further seven are conservation listed and more than 60 are first citations for Shetland. Amongst the fungi is an Entoloma sp. which could yet prove to be an undescribed species. The CHEGD grassland fungi are notably represented. This is a group endangered throughout Europe as their unimproved habitat is lost to modern agriculture (Arnolds, 1989; Eriksson et al., 1995; Lovegrove et al., 1995). There is a strong Nordic theme to some exceptional montane taxa, particularly associated with Salix herbacea. For its size (768 ha), Fair Isle registers an impressively rich fungus "flora" of regional, national and international importance.

\section{ACKNOWLEDGEMENTS}

It is pleasing to acknowledge the high level of interest amongst Fair Islanders with special mention of Elizabeth Riddiford, Rachel Challoner, Luca Rotolo, the Thomson and Parnaby families. Alison Murfitt made an important contribution in a three-day visit in 2011. The two reviewers are thanked for their input to the final draft. The authors dedicate this paper to inspirational Shetland Naturalist, the late Bobby Tulloch, who pioneered the study of Shetland fungi including Fair Isle as well as warmly hosting RW and helping him to reach otherwise difficult localities during his many trips to Shetland and its islands.

\section{REFERENCES}

Arnolds, E. (1986). Notes on Hygrophoraceae - VIII. Taxonomic and nomenclatural notes on some taxa of Hygrocybe. Persoonia 13, 137-160.

Arnolds, E. (1989). The influence of increased fertilization on the macrofungi of a sheep meadow in Drenthe, the Netherlands. Opera Botanica 100, 721.

Dennis, R.W.G. (1960). British Cup Fungi and their Allies. Ray Society, London.

Dennis, R.W.G. (1972). Fungi of the Northern Isles. Kew Bulletin 26, 427-432. https://doi.org/10.2307/4120305

Dennis, R.W.G. \& Gray, E. (1954). A first list of the fungi of Zetland (Shetland). Transactions of the Botanical Society of Edinburgh 36, 205-223. https://doi.org/10.1080/13594865409441610

Eriksson, A., Eriksson, O. \& Berglund, H. (1995). Species abundance patterns of plants in Swedish semi-natural pastures. Ecography 18, 310-317. https://doi.org/10.1111/j.1600-0587.1995.tb00133.x

Hora, F.B. (1957). The genus Panaeolus in Britain. The Naturalist 1957, 77-88.

Kühner, R. (1975). Agaricales de la Zone Alpine: genre Russula Pers. ex S. F. Gray. Bulletin de la Société mycologique de France 91, 313-390.

Legon, N.W., Henrici, A., Roberts, P.J., Spooner, B.M. \& Watling, R. (2005). Checklist of the British \& Irish Basidiomycota. Royal Botanic Garden, Kew.

Lovegrove, R., Shrubb, M. \& Williams, I. (1995). Silent Fields. RSPB Wales.

Milner, J.E.D. (2006). An annotated list of Shetland spiders and pseudoscorpions, including new records up to 2005. Shetland Naturalist 2(3), 83-96.

Moeller, F.H. (1945). Fungi of the Faeroes. Part 1. Basidiomycetes. Munksgaard, Copenhagen.

Murfitt, A. (2011). Grassland Fungi Survey, September 2011. BTCV/NTS draft report, unpublished.

Price, S. (2017). Lichens and lichenicolous fungi of Fair Isle: an annotated checklist. Fair Isle Bird Observatory Report 68, 71-187.

Orton, P.D. (1960). New check list of British agarics and boleti. Transactions of the British Mycological Society 43(2), 159-439. https://doi.org/10.1016/S0007-1536(60)80065-4

Quinteros Peñafiel, C.V., Riddiford, N.J. \& Twyford, A.D. (2017). A floristic survey of Fair Isle. New Journal of Botany 7, 101-111. https://doi.org/10.1080/20423489.2017.1393191

Riddiford, N.J., Watling, R. \& Murfitt, A. (2020). Grassland Fungi. FIBO, Fair Isle. http://www.fairislebirdobs.co.uk/grassland_fungi.ht $\mathrm{ml}$

Riddiford, N.J. \& Watling, R. (2020a). RSPB Management News: Response of grassland fungi to an agricultural change. British Wildlife 31, 412-413. 
Riddiford, N.J. \& Watling, R. (2020b). Response of Grassland Fungi to an Agricultural Change. FIBO, Fair Isle.

http://www.fairislebirdobs.co.uk/grassland_fungi.ht $\mathrm{ml}$

Rotheroe, M., Newton, A., Evans, S. \& Feehan, J. (1996). Waxcap-grassland survey. The Mycologist 10, 23-25.

https://doi.org/10.1016/S0269-915X(96)80046-2

Scott, W. \& Palmer, R. (1987). The Flowering Plants and Ferns of the Shetland Islands. The Shetland Times Ltd., Lerwick, Shetland.

Watling, R. (1992). The Fungus Flora of Shetland. Royal Botanic Garden, Edinburgh.

Watling, R., King, R. \& Riddiford, N.J. (2001). New and interesting records of fungi from Shetland. Botanical Journal of Scotland 53(1), 57-64. https://doi.org/10.1080/03746600108684955

Watling, R. \& Riddiford, N.J. (1986). Fair Isle fungi list, 1985. FIBO Report 38, 83-84.

Watling, R. \& Riddiford, N.J. (1987). Additions to the Fair Isle fungi list, 1986. FIBO Report 39, 65. 


\section{APPENDIX}

Ordnance Survey grid references for locations mentioned in the text

Fair Isle belongs to vice-county 112 (Shetland) for recording purposes.

$\begin{array}{ll}\text { Airstrip HZ211721 } & \text { Hesti Geo HZ198702 } \\ \text { Back of Houll HZ204707 } & \text { Hill Grazings HZ27 } \\ \text { Barkland HZ208711 } & \text { Hjukni Geo HZ202711 } \\ \text { Bird Observatory HZ222723 } & \text { Hoini HZ203714 } \\ \text { Boini Mire HZ205706 } & \text { Houll Cuppas HZ205706 } \\ \text { Breckawalls HZ207709 } & \text { Kenaby HZ207702 } \\ \text { Breed Piece HZ210723 } & \text { Kirk HZ206706 } \\ \text { Bullock Holes HZ219727 } & \text { Kirki Geo HZ200698 } \\ \text { Buness HZ2272 } & \text { Leogh HZ201702 } \\ \text { Burkle HZ204702 } & \text { Linni Geo HZ199706 } \\ \text { Byerwall HZ2171 } & \text { Lower Station HZ211731 } \\ \text { Chatham's Land HZ208710 } & \text { Lower Stoneybrek HZ20547092 } \\ \text { Ditfield HZ221721 } & \text { Malcolm's Head HZ198704 } \\ \text { Eas Brecks HZ2172 } & \text { Mavers Geo HZ222723 } \\ \text { Field HZ21117 71524 } & \text { Meoness HZ205697 } \\ \text { Furse HZ224732 } & \text { Midway HZ202705 } \\ \text { Gilsetter HZ214718 } & \text { North Grind HZ212717 } \\ \text { Grand Canyon HZ209723 } & \text { North Haven HZ224725 }\end{array}$

North Light HZ221740

North Naaversgill HZ203726

Plantation HZ212717

Pund HZ206714

Rippack HZ20647064

Quoy HZ204704

School HZ207709

Schoolton HZ204704

Setter HZ209715

Shalstane HZ197699

Shirva HZ202709

South Haven HZ224724

South Light HZ197688

South Light Brae HZ197697

Springfield HZ207699

Stackhoull Stores HZ204708

Stonybreck HZ205709

Sukka Mire HZ208721
Swarts Geo HZ209702

Swey HZ213734

Taing HZ208709

Tarryfield HZ208718

The Haa HZ202700

Upper Leogh HZ201702

Utra Brae HZ198699

Vaadal Plantation HZ212717

Vaila's Trees HZ204708

Valsbrough HZ2070

Vatstrass HZ217721

Ward Hill HZ208734

Ward Hill north slope HZ20827343

Wester Lother HZ211738

Ward Hill summit HZ20847341

Wirvie HZ217736 